\title{
PERANCANGAN APLIKASI SISTEM E-PURCHASING DENGAN PENDEKATAN KONSEP VALUE MATRIX PADA PROSES PEMESANAN BAHAN BAKU PERUSAHAAN SPRINGBED
}

\author{
Carla Olyvia Doaly, Ahmad, Erwin Tanuwijaya \\ Program Studi Teknik Industri Universitas Tarumanagara \\ e-mail: carlaol@ft.untar.ac.id; ahmad@ft.untar.ac.id; erwintanuwijaya2@gmail.com
}

\begin{abstract}
ABSTRAK
Perusahaan manufaktur penghasil Springbed yang berlokasi di Tangerang, memiliki tugas menerima pemesanan bahan baku untuk keperluan produksi dari seluruh cabang yang tersebar di seluruh daerah di Indonesia. Pemesanan bahan baku saat ini masih menggunakan sistem manual yaitu menggunakan email. Adapun Departemen yang terlibat pada proses pemesanan bahan baku terdiri dari 6 Departemen, yaitu Departemen Purchasing AKA, Departemen Admin Stok, Departemen Purchasing Cabang, Departemen Gudang Bahan Baku AKA, Gudang Bahan Baku Cabang. Data dari 6 Departemen ini belum terintegrasi dengan baik. sehingga sering terjadi kesalahan pada pemrosesan bahan baku dan pemesanan yang melewati batas yg ditentukan. Akibatnya, bahan baku tidak terpenuhi, pemesanan menjadi lama dan produksi menjadi terhambat. Penelitian ini bertujuan untuk merancang sebuah sistem proses pemesanan bahan baku e-Purchasing yang terintegrasi berbasis E-Supply Chain dengan pendekatan Konsep Value Matrix. Hasil yang didapat dari rancangan E-Purchasing ini adalah seluruh proses pemesanan bahan baku terintegrasi mencakup semua departemen terkait adanya katalog bahan baku dan proses pemesanan bahan baku dapat berjalan tepat waktu sesuai dengan ketentuan perusahaan.
\end{abstract}

Kata kunci: Integrasi Proses Pemesanan Material, E-Purchasing, E-Supply Chain, Konsep Value Matrix.

\begin{abstract}
A springbed manufacturing company located in Tangerang, has the task of receiving orders for raw materials for the purposes of production from all branches spread across all regions in Indonesia. Ordering raw materials is currently still using a manual system that is using email. The Department involved in ordering raw materials consists of 6 Departments, namely AKA Purchasing Department, Stock Admin Department, Purchasing Branch Department, AKA Raw Material Warehouse Department, Raw Material Warehouse Branch. Data from these 6 Departments has not been well integrated. so there are often errors in processing raw materials and orders that exceed the specified limit. As a result, raw materials are not met, orders are long and production is hampered. This study aims to design an integrated ePurchasing raw material ordering system based on E-Supply Chain based on the Value Matrix Concept approach. The results obtained from this E-Purchasing design are that the whole process of ordering raw materials includes all departments related to the existence of a catalog of raw materials and the process of ordering raw materials can run on time in accordance with company regulations.
\end{abstract}

Keywords: Integration of Materials Ordering Process, E-Purchasing, E-Supply Chain, Value Matrix Concept.

\section{PENDAHULUAN}

Industri Spring bed di Indonesia berkembang dalam beberapa tahun ini, hal ini disebabkan oleh meningkatnya pertumbuhan penduduk yang menyebabkan pembangunan rumah dan apartemen yang ikut meningkat. Dengan demikian, industri Spring bed juga ikut meningkat, berbanding lurus dengan meningkatnya pembangunan rumah dan apartemen [1]. Suatu perusahaan yang bergerak di bidang manufaktur produk Spring bed berlokasi di Tangerang, saat ini telah memiliki berbagai cabang pabrik di berbagai daerah Indonesia. Dalam produksi spring bed, ketersediaan bahan baku merupakan hal yang 
Perancangan Aplikasi Sistem E-Purchasing dengan Pendekatan Konsep Value Matrix pada Proses Pemesanan Bahan Baku

\section{Carla Olyvia Doaly, Ahmad, Erwin Tanuwijaya}

sangat penting. Sebagai pusat penyimpanan bahan baku untuk keperluan produksi sendiri dan keperluan pabrik cabang lainnya perusahaan harus dapat memenuhi semua kebutuhan. Setiap pabrik cabang melakukan permintaan sesuai dengan kebutuhannya dengan harga yang telah ditetapkan oleh perusahaan. Semua permintaan bahan baku dari setiap pabrik cabang akan diterima dan dipisahkan sesuai dengan supplier terkait. Data permintaan bahan baku dari setiap cabang dan proses permintaan pada setiap supplier masih menggunakan sistem manual. Hal ini menyebabkan seringnya terjadi kesalahan antara pabrik cabang maupun kepada supplier sehingga bahan baku tidak sampai tepat waktu yang mengakibatkan terhambatnya proses produksi.

Penelitian ini dilakukan untuk mendapatkan integrasi proses penerimaan permintaan bahan baku dari seluruh cabang dan proses pemesanan bahan baku dengan merancang suatu aplikasi sistem E-Purchasing untuk setiap supplier dengan berbasis E-Supply Chain. Sehingga proses pemesanan bahan baku dapat dilakukan dengan lebih mudah dan cepat.

\section{TINJAUAN PUSTAKA}

E-supply chain management merupakan konsep penerapan manajemen rantai pasok pada perusahaan dengan menggunakan internet. Sehingga aliran informasi pada seluruh departemen dapat dilakukan dengan lebih cepat, efektif, dan efisien. Hal ini dikarenakan akses internet dapat menyediakan informasi yang dibutuhkan setiap saat.

Dengan adanya integrasi antara pemasok, produsen dan distributor, keunggulan antar jaringan kelompok perusahaan pun akan muncul. Sebab pengembangan kinerja yang dilakukan tidak hanya pada satu perusahaan saja, melainkan seluruh rantai jaringan distribusi dari satu produk menjadi kunci pengembangan yang mampu menaikkan daya saing global [2]. Sehingga dapat disimpulkan bahwa E-Supply Chain Management merupakan sebuah taktik dan strategi yang diterapkan dalam teknologi internet sebagai channel system yang menghubungkan semua organisasi yang terlibat dalam supply chain untuk meningkatkan pelayanan atau memberikan manfaat pada customer.

Transformasi Supply chain tradisional menjadi e-supply chain management dimulai pada tahun 2000-an. Dimana fase ini memberikan suatu konsep inovasi dan perkembangan baru terhadap kinerja rantai pasok dalam sebuah perusahaan [3]. Dengan terus berkembangnya jaringan internet, e-supply chain management menjadi semakin mungkin untuk dilakukan. Dengan adanya kebutuhan organisasi untuk mendapatkan daya saing respon terhadap supplier dan customer yang cepat, mudah dan menampilkan data real, $e$ supply chain management semakin banyak diterapkan oleh beberapa perusahaan.

Proses bisnis yang menggunakan akses internet memiliki perbedaan nyata jika dibandingkan dengan proses bisnis secara nyata. Terdapat tiga jenis keunggulan dalam menggunakan sistem berbasis internet, antara lain:

\section{Kemampuan Visibility}

Kemampuan visibility adalah kemampuan perusahaan perusahaan dapat melihat, memantau, dan mengendalikan proses bisnis perusahaan tanpa harus pergi melihat operasi perusahaan secara langsung. Dengan adanya sistem informasi dan teknologi, informasi memberikan perusahaan kemampuan untuk 'melihat' proses bisnis perusahaan secara efektif.

\section{Kemampuan Mirroring (Mirroring Capability)}

Mirroring Capability adalah sebuah virtual sistem yang diaplikasikan untuk menggantikan proses bisnis nyata di lapangan yang membutuhkan lebih banyak waktu, biaya, dan tenaga. 


\section{New Customer Relationships}

New Customer Relationships merupakan sebuah sistem yang memanfaatkan teknologi internet sebagai wadah atau kesempatan perusahaan tersebut dalam memperluas jaringan konsumen dan membuat sebuah jaringan hubungan dengan konsumen baru. Sebagai contoh seperti perusahaan Amazon.com yang sekarang ini dengan kreatif memanfaatkan internet untuk menciptakan sebuah hubungan dengan konsumen baru.

Dalam Penelitian ini menggunakan pendekatan konsep Value Matrix merupakan konsep strategi dengan mengintegrasikan Physical Value Chain dengan Virtual Value Chain untuk menciptakan sebuah sistem baru dengan memiliki keunggulan yang kompetitif. Informasi menggunakan data mentah yang digunakan dalam sistem vitual value chain [4-5]. Dengan demikian, tahapan dari pengubahan nilai pada informasi yang tersedia, antara lain adalah sebagai berikut.

1. Gathering, merupakan proses dari pengumpulan data berupa informasi yang akan digunakan untuk proses perancangan sistem E-Purchasing. Pada tahap ini juga akan dilakukan pengumpulan data proses pemesanan bahan baku yang selama ini terjadi dilapangan, analisa perbedaan secara aktual dengan sistem E-Purchasing yang akan dirancang .

2. Organizing, merupakan proses dari mengintegrasikan antar data yang akan dimasukkan pada sistem dengan merancang data flow diagram.

3. Selecting. merupakan proses pemilihan data apa saja yang akan digunakan dengan merancang permodelan E-Purchasing sistem yang akan dibuat dengan menggunakan bantuan model konseptual UML [6].

4. Synthesizing, informasi akan digabungkan menjadi satu sistem yang satu dan utuh. Akan dilakukan analisa mengenai proses pembuatan tabel yang akan digunakan dalam database sistem e-Purchasing.

5. Distributing, merupakan proses distrubusi yaitu penggunaan kepada pihak yang membubtuhakan sistem yang dirancang dengan menggunakan jaringan internet dengan data yang telah digabungkan. Tahapan distributing merupakan tahapan implementasi sistem E-Purchasing yang dirancang.

Pendekatan konsep Value Matrix dapat dilihat pada Gambar 1 berikut ini.

\begin{tabular}{|c|c|c|c|}
\hline & & & \multirow{2}{*}{$\begin{array}{l}\text { Physical Value Chain } \\
\text { Gather }\end{array}$} \\
\hline Gather & Gather & Gather & \\
\hline Organize & Organize & Organize & Organize \\
\hline Select & Select & Select & Select \\
\hline Synthesize & Synthesize & Synthesize & Synthesize \\
\hline Distribute & Distribute & Distribute & Distribute \\
\hline & & & Virtual Value Chain \\
\hline
\end{tabular}

Gambar 1. Konsep Value matrix

\section{METODOLOGI PERANCANGAN}

Dalam penelitian ini, perancangan sistem proses pemesanan bahan baku dilakukan dengan tahapan yang dapat dilihat pada Gambar 2 berikut ini. 

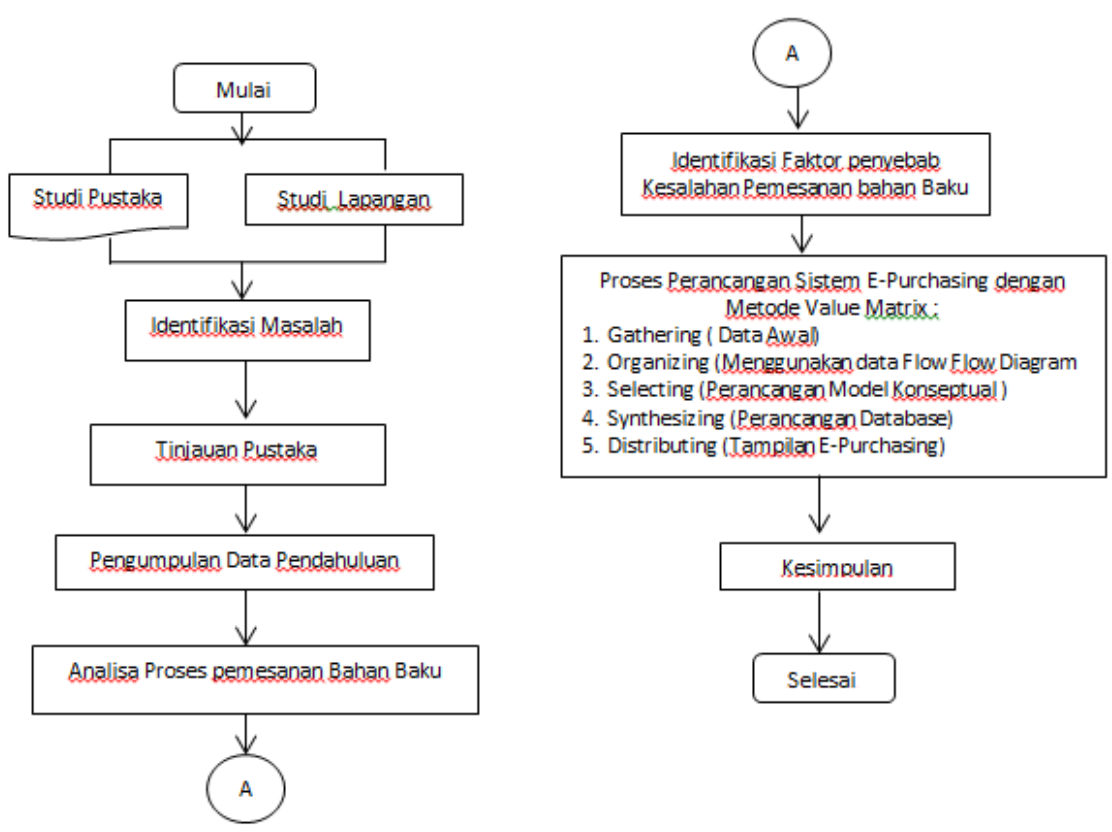

Gambar 2. Flowchart Metodologi Perancangan

Dalam penelitian ini tahapan pertama yang dilakukan adalah menganalisa proses pemesanan bahan baku yang terjadi saat ini. kemudian pengumpulan data-data dari seluruh departemen terkait yang berkaitan dengan proses pemesanan bahan baku, kemudian melakukan analisa yang akan digunakan untuk menentukan rancangan dari desain sistem pemesanan bahan baku terintegrasi yang akan dibangun. Sebelum merancang sistem integrasi, dilakukan identifikasi faktor dari penyebab kesalahan pemesanan bahan baku yang selama ini terjadi. Identifikasi ini kemudian akan digunakan untuk merancang perbaikan sistem dengan kondisi sesuai di lapangan. Akan didapatkan akar dari permasalahan pada pemesanan bahan baku, kemudian akan dirancang sistem E-Purchasing dengan pendekatan konsep Value Matrix yang terdiri dari tahapan gathering, organizing, selecting, synthesizing, dan distributing.

\section{HASIL DAN PEMBAHASAN Proses Pemesanan Material}

Proses Pemesanan Bahan baku pada PT. Anugrah Karya Aslindo saat ini masih menggunakan proses pemesanan secara manual baik antara pabrik cabang untuk melakukan order bahan baku pada PT. Anugrah Karya Aslindo maupun pemesananan kepada supplier. Departemen yang terlibat dalam proses pemesanan bahan baku ada 5, yaitu Departemen Purchasing Cabang, Departemen Purchasing AKA, Departemen Admin Stok, Departemen Gudang bahan baku, Departemen Gudang bahan baku cabang. Proses pemesanan bahan baku kepada supplier dilakukan oleh bagian Purchasing AKA. Departemen Purchasing AKA setiap bulannya akan menerima formulir permintaan bahan baku yang akan diberikan oleh admin stok dan menerima PO dari bagian Purchasing cabang-cabang. Bagian Purchasing akan menjumlahkan setiap kebutuhan bahan baku dari setiap cabang (8 cabang). Setelah menjumlahkan setiap kebutuhan bahan baku, Departemen Purchasing AKA akan melakukan proses pemilihan supplier. Dikarenakan bahan baku yang akan dipesan berjumlah besar, terkadang untuk satu jenis bahan baku 
supplier tidak dapat memenuhi semuanya. Dengan demikian untuk 1 jenis bahan baku terkadang terdapat beberapa supplier yang akan memenuhi kebutuhan bahan baku tersebut.

Staf Purchasing akan mendapatkan Purchase Order berupa e-mail (dari purchasing cabang) dan kertas manual dari admin stok. Pihak gudang bahan baku akan menerima bahan baku yang dikirim oleh supplier dan akan melakukan pengecekan apakah sesuai dengan jumlah yang dipesan. Staf Gudang bahan baku akan mengirimkan pesanan dari setiap cabang untuk dikirim dengan berkordinasi dengan admin stok untuk pembuatan surat jalan.

\section{Analisis Proses Pemesanan Material}

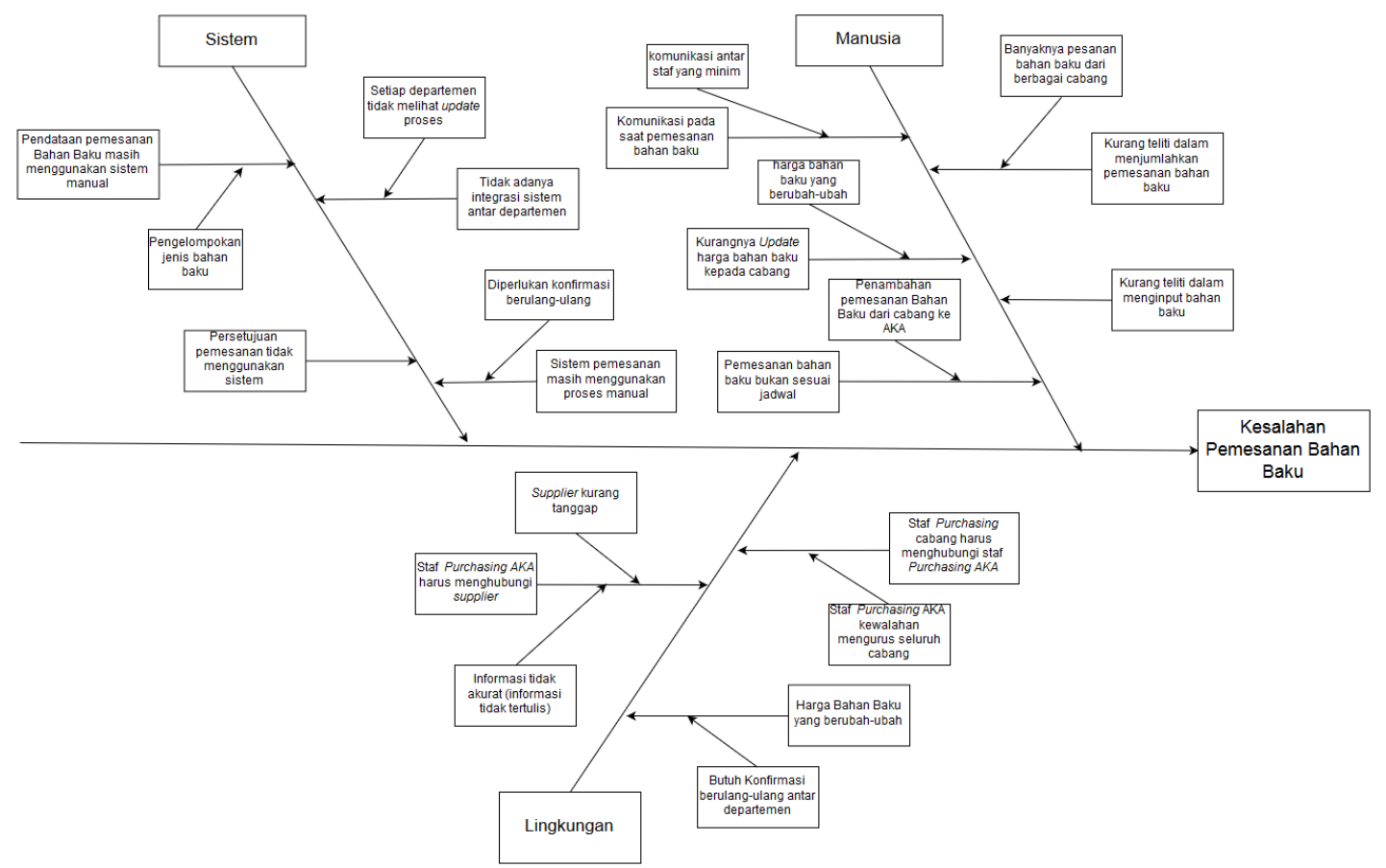

Gambar 3. Fishbone Diagram Analisa Kesalahan Pemesanan Bahan Baku

Pada Gambar 3 ditunjukkan Diagram Fishbone dari Analisa Kesalahan Bahan Baku. Diagram tersebut menyimpulkan bahwa selama ini kesalahan pada pemesanan bahan baku karena sistem dari perusahaan masih menggunakan proses manual, sehingga dibutuhkan konfirmasi berulang antar departemen. Staf Purchasing cabang juga harus memisahkan bahan baku pesananan dari seluruh cabang berdasarkan jenisnya secara manual. Sehingga menimbulkan seringnya terjadi kesalahan dalam pemesanan bahan baku kepada supplier. Proses pemesanan bahan baku secara manual juga menyebabkan tidak disiplinnya setiap cabang dalam memesan bahan baku sesuai dengan jadwal pemesanan yang telah ditentukan dan sulitnya memberikan informasi proses bahan baku yang telah dipesan kepada setiap departemen terkait.

\section{Perancangan Integrasi Proses Pemesanan Bahan Baku Menggunakan Konsep Value Matrix}

Perancangan sistem dilakukan dalam lima tahapan, tahapan tersebut antara lain adalah:

a) Gathering

Data yang dikumpulkan merupakan proses pemesanan bahan baku yang selama ini dilakukan yaitu data material springbed, harga material, data supplier, data permintaan bahan baku cabang. 
Perancangan Aplikasi Sistem E-Purchasing dengan Pendekatan Konsep Value Matrix pada Proses Pemesanan Bahan Baku

\section{Carla Olyvia Doaly, Ahmad, Erwin Tanuwijaya}

b) Organizing

Organizing merupakan proses dari pengaturan seluruh data awal yang telah dikumpulkan menjadi sebuah data flow diagram (DFD) yang akan dirancang yang dapat dilihat pada Gambar 4 menunjukkan data yang akan dirancang merupakan data flow diagram Level 0.

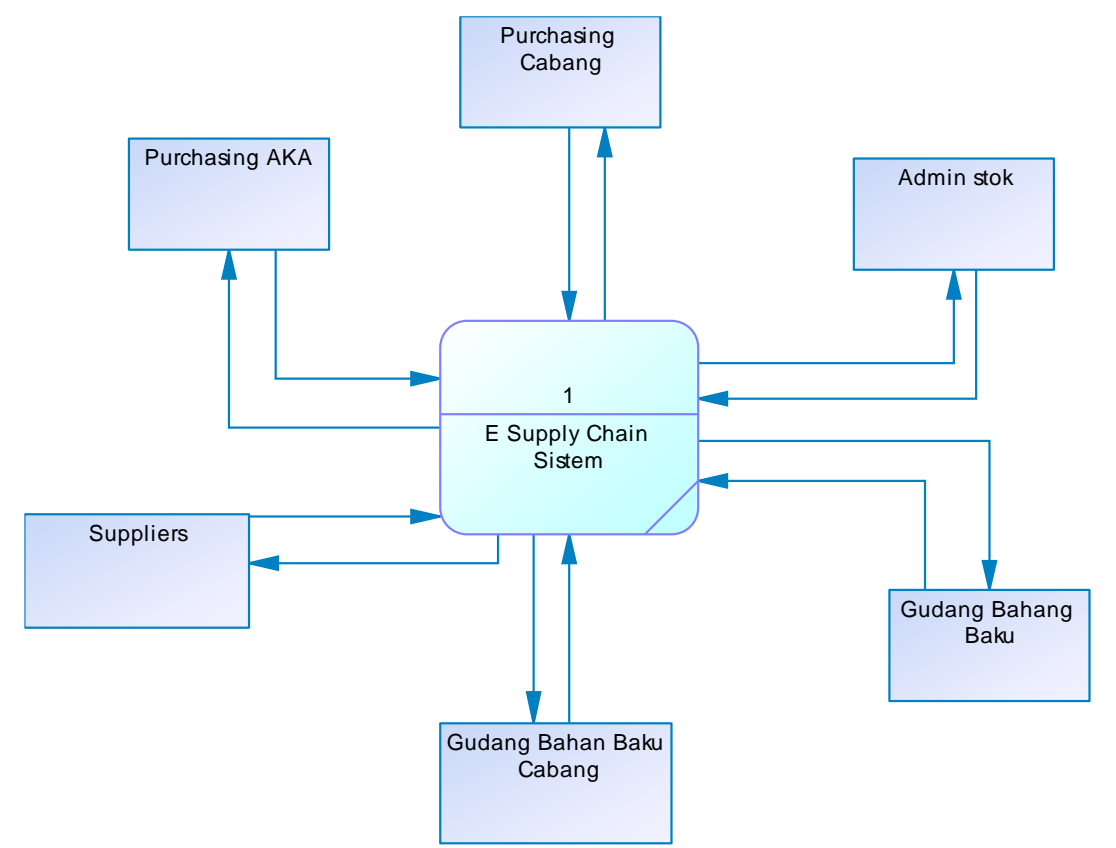

Gambar 4. Data Flow Diagram Level 0

\section{c) Selecting}

Proses selecting akan merancang interkasi antar user atau pengguna dari sistem. Interaksi dari user tersebut digambarkan pada diagram usecase seperti pada Gambar 5. Proses perancangan model konseptual dimulai dengan use case diagram, sequence diagram, dan activity diagram. Setelah mengetahui interaksi pengguna dengan sistem yang akan dirancang, kemudian selanjutnya merancang activity diagram untuk mengetahui aktivitas user atau pengguna saat menggunakan sistem E-Supply Chain. Gambar Activity Diagram dapat dilihat pada Gambar 6. Tahapan selanjutnya setelah menyusun interaksi antar departemen dalam penggunaan sistem e-supply chain adalah perancangan pemodelan tahapan penggunaan sistem secara terperinci dengan mengggunakan Sequence Diagram yang dapat dilihat pada Gambar 7 berikut.

\section{d) Synthesizing Data}

Proses sintesis merupakan penggabungan seluruh data dan konsep pengelolaan data yang ada ke dalam satu database. Langkah awal sebelum membuat database adalah menjelaskan fitur maupun halaman yang akan dirancang. Sistem $e$-supply chain dirancang sesuai dengan fungsi entitas yang menggunakan sistem e-supply chain ini. Sehingga setal tampilan pada tiap entitas akan berbeda sesuai dengan fungsi atau tugas masing masing dalam proses pemesanan bahan baku. Tugas masing-masing entitas dalam sistem $e$-supply chain ini adalah: 


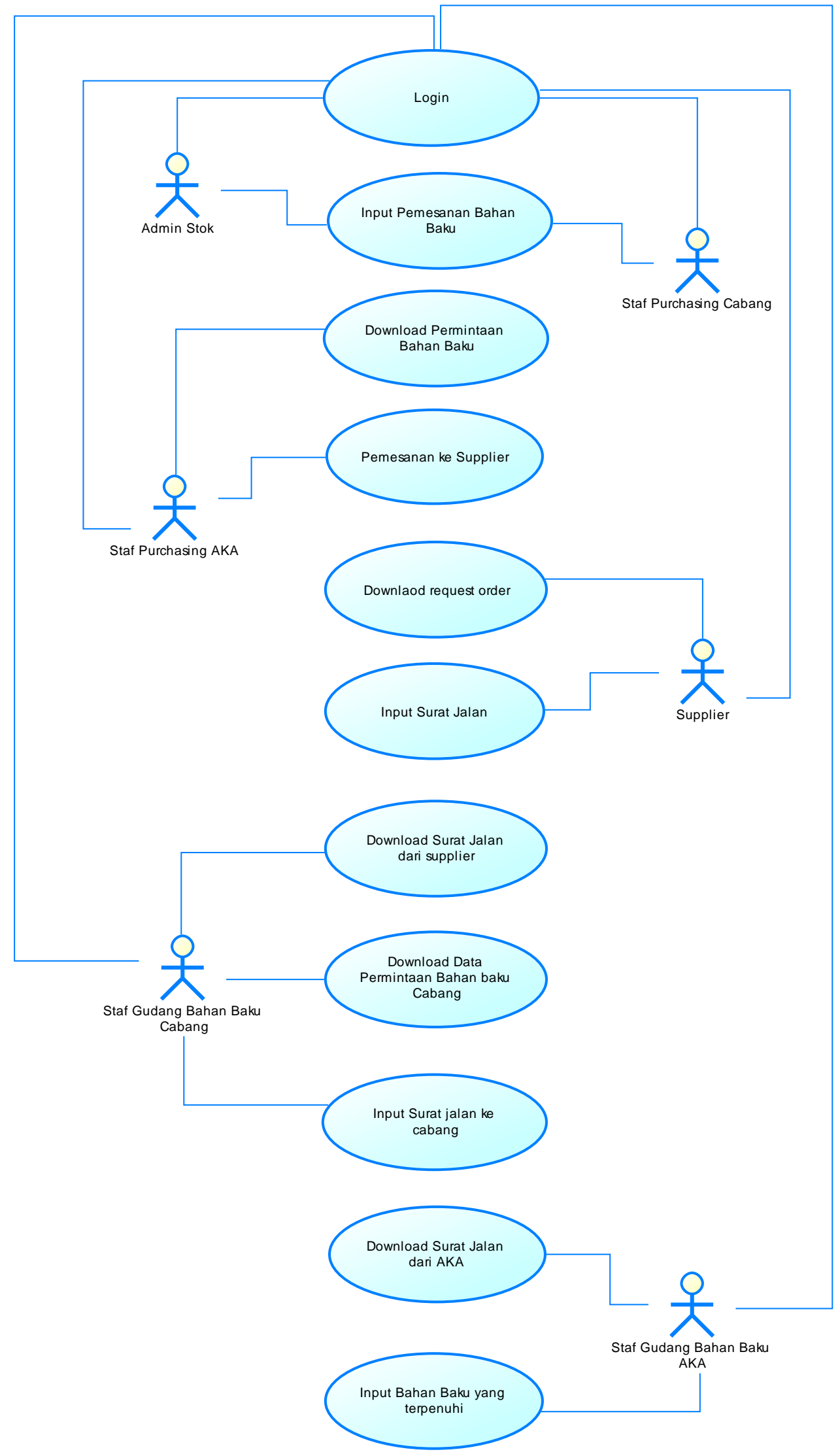

Gambar 5. Use Case Diagram 
Perancangan Aplikasi Sistem E-Purchasing dengan Pendekatan Konsep Value Matrix pada Proses Pemesanan Bahan Baku

Carla Olyvia Doaly, Ahmad, Erwin Tanuwijaya

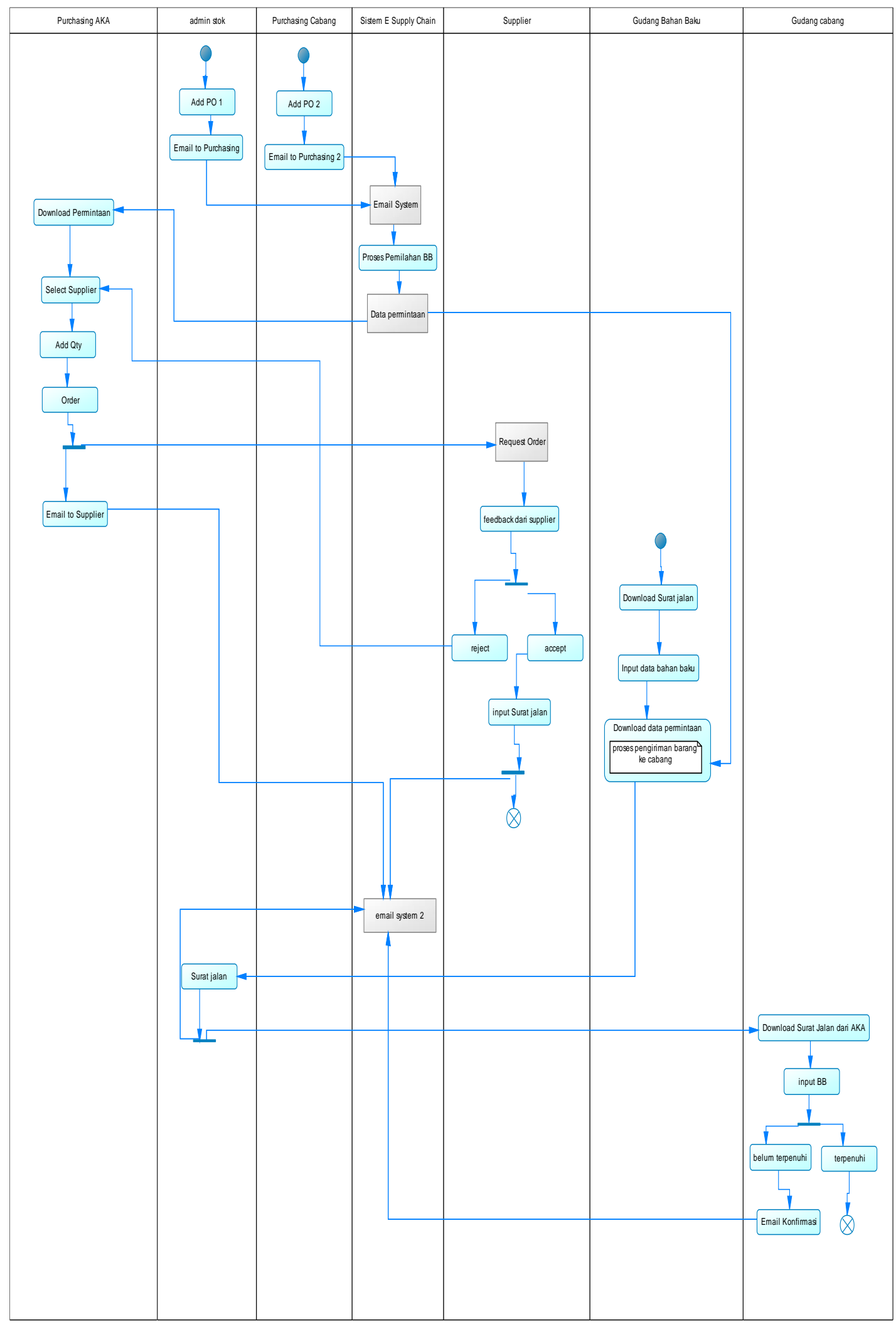

Gambar 6. Activity Diagram 


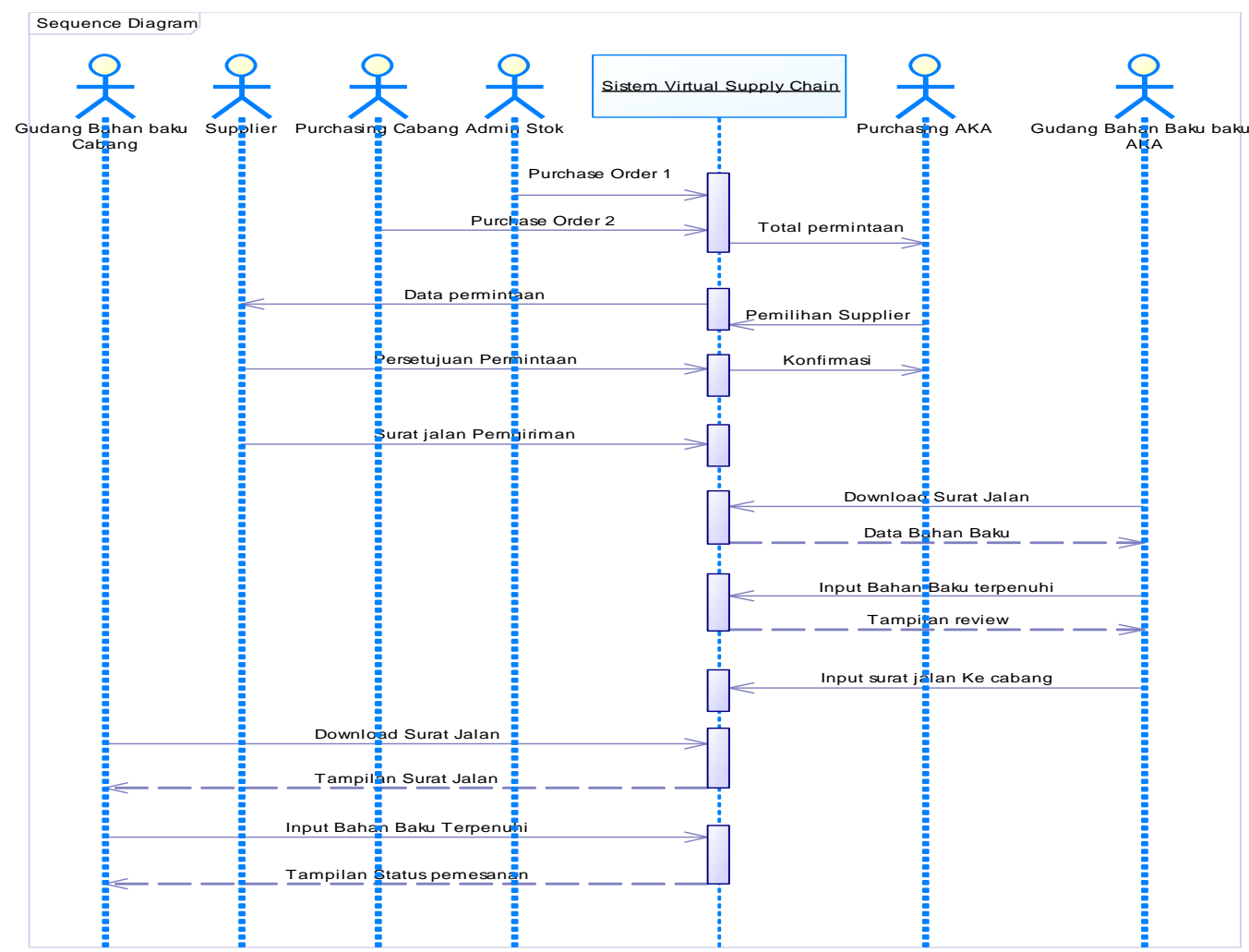

\section{Gambar 7. Diagram Sequence Secara Keseluruhan}

Tabel 1 berikut menjelaskan mengenai hasil rancangan fitur sistem E-Purchasing beserta tugas dari masing-masing entitas dalam hal ini departemen yang terkait dalam sistem yang dirancang. Saat ini pentingnya perpaduan antara sistem fisik dan sistem virtual dalam industry 4.0 [7] mendorong sistem bisnis untuk terus meningkatkan sistemnya.

\section{Tabel 1. Fitur Sistem E-Purchasing}

\begin{tabular}{|c|c|c|}
\hline Entitas & Role atau Tugas & Fitur Dalam E-Purchasing \\
\hline Purchasing AKA & $\begin{array}{l}\text { Purchasing AKA memiliki tugas } \\
\text { untuk menerima Purchase Order } \\
\text { bahan baku dari setiap cabang dan } \\
\text { melaukan proses pemesanan bahan } \\
\text { baku kepada supplier sesuai dengan } \\
\text { jenis bahan baku }\end{array}$ & $\begin{array}{l}\text { 1. Purchasing AKA dapat mendapatkan informasi data } \\
\text { pemesanan bahan baku yang dikirimkan oleh admin } \\
\text { stok dan purchasing cabang dalam bentuk email dan } \\
\text { dapat di download. } \\
\text { 2. Bahan baku yang dipesan oleh admin stok dan } \\
\text { purchasing cabang sudah langsung dipisahkan } \\
\text { menurut jenis bahan baku sehingga memudahkan } \\
\text { purchasing AKA untuk memesan bahan baku } \\
\text { kepada supplier } \\
\text { 3. Pada proses Request Order kepada supplier, } \\
\text { Purchasing AKA melakukan penginputan bahan } \\
\text { baku hanya dengan memilih bahan baku yang sudah } \\
\text { dimasukkan di dalam data base bahan baku seusai } \\
\text { dengan nama supplier dan jenis bahan bakunya. } \\
\text { 4. Request order bahan baku kepada supplier } \\
\text { dikirimkan dalam bentuk email yang sudah ada di } \\
\text { dalam database sehingga purchasing AKA tidak } \\
\text { perlu membuat email setiap kali jika ingin memesan } \\
\text { bahan baku kepada supplier } \\
\text { 5. Purchasing AKA dapat melihat review pemesanan } \\
\text { bahan baku setelah melakukan pemesanan kepada } \\
\text { supplier untuk mengecek kembali apakah ada } \\
\text { kesalahan pada pemesanan bahan baku. }\end{array}$ \\
\hline
\end{tabular}


Perancangan Aplikasi Sistem E-Purchasing dengan Pendekatan Konsep Value Matrix pada Proses Pemesanan Bahan Baku

Carla Olyvia Doaly, Ahmad, Erwin Tanuwijaya

Lanjutan Tabel 1. Fitur Sistem E-Purchasing

\begin{tabular}{ll}
\hline Entitas & \multicolumn{3}{c}{ Role atau Tugas } \\
\hline & Admin Stok memiliki tugas \\
& memesan bahan baku kepada \\
& purchasing AKA dan membuat surat \\
& jalan pengiriman bahan baku kepada \\
& cabang-cabang
\end{tabular}

Admin Stok cabang-cabang Fitur Dalam E-Supply Chain

1. Data jenis baku sudah ada di database berupa jenis bahan baku dan harga

2. Setalah melakukan pemesanan kepada Purchasing AKA, Admin stok dapat melihat review order dari pemesanan bahan baku.

3. Format email pemesanan bahan baku sudah ada di dalam database, sehingga tidak perlu membuat email setiap kali melakukan pemesanan bahan baku

4. Surat jalan pengiriman bahan baku kepada setiap cabang tersedia pada database, admin stok hanya perlu menginput jenis, nama dan jumlah bahan baku sesuai dengan yang akan dikirimkan.

\begin{tabular}{|c|c|c|}
\hline $\begin{array}{l}\text { Purchasing } \\
\text { Cabang }\end{array}$ & $\begin{array}{l}\text { Purchasing Cabang memiliki tugas } \\
\text { untuk memesan bahan baku kepada } \\
\text { Purchasing AKA }\end{array}$ & $\begin{array}{l}\text { 1. Data jenis bahan baku sudah ada di database berupa } \\
\text { jenis bahan baku dan harga } \\
\text { 2. Purchasing cabang dapat melihat review order } \\
\text { setalah melakukan pemesanan kepada purchasing } \\
\text { AKA. } \\
\text { 3. Format email pemesanan bahan baku telah tersedia } \\
\text { didalam database, sehingga purchasing cabang tidak } \\
\text { perlu membuat email setiap kali melakukan } \\
\text { pemesanan kepada Purchasing AKA. }\end{array}$ \\
\hline Supplier & $\begin{array}{l}\text { Supplier memiliki tugas untuk } \\
\text { menerima request order dari } \\
\text { purchasing AKA dan akan memilih } \\
\text { untuk menerima atau ditolak. } \\
\text { Supplier juga bertugas untuk } \\
\text { membuat surat jalan untuk bahan } \\
\text { baku yang dikirimkan. }\end{array}$ & $\begin{array}{l}\text { 1. Supplier dapat mendownload request order dari } \\
\text { sistem dalam bentuk format email dengan detail } \\
\text { pemesanan. } \\
\text { 2. Surat jalan pengiriman bahan baku kepada } \\
\text { Purchasing AKA sudah ada didalam database. } \\
\text { Supplier hanya menginput jenis bahan baku, nama, } \\
\text { dan jumlah bahan baku yang akan dikirimkan. Surat } \\
\text { jalan akan berbentuk email yang akan diterima oleh } \\
\text { purchasing AKA. } \\
\text { 3. Menginput surat jalan kepada sistem dengan format } \\
\text { yang telah tersedia dengan memilih jenis bahan } \\
\text { baku, jumlah bahan baku dan keterangan lainnya. } \\
\text { Surat jalan akan langsung jadi dengan format yang } \\
\text { telah ada. }\end{array}$ \\
\hline $\begin{array}{c}\text { Gudang Bahan } \\
\text { Baku }\end{array}$ & $\begin{array}{l}\text { Gudang bahan baku bertugas untuk } \\
\text { mendownload surat } r \text { jalan } \\
\text { pengiriman bahan baku dan } \\
\text { menginput kedalam sistem, } \\
\text { mencocokkan jumlah bahan yang } \\
\text { dikirimkan oleh supplier dan } \\
\text { mengelompokkan bahan baku sesuai } \\
\text { dengan jenisnya. Gudang bahan } \\
\text { baku juga bertugas untuk } \\
\text { mendownload data permintaan } \\
\text { bahan baku cabang untuk } \\
\text { mengirimkannya kepada setiap } \\
\text { cabang }\end{array}$ & $\begin{array}{l}\text { 1. Surat jalan pengiriman barang dari supplier dapat } \\
\text { di download untuk mencocokkan bahan baku yang } \\
\text { dikirim oleh supplier. } \\
\text { 2. Bahan baku yang sudah datang akan diinput } \\
\text { kedalam sistem sesuai dengan jenis dan } \\
\text { jumlahnya. } \\
\text { 3. Gudang bahan baku dapat mendownlaod } \\
\text { permintaan bahan baku yang terdapat dalam sistem } \\
\text { dari setiap cabang untuk melakukan proses } \\
\text { pengiriman bahan baku yang telah dipesan } \\
\text { sebelumnya }\end{array}$ \\
\hline $\begin{array}{c}\text { Gudang Bahan } \\
\text { Baku Cabang }\end{array}$ & $\begin{array}{l}\text { Gudang bahan baku cabang memiliki } \\
\text { tugas mendownload surat jalan yang } \\
\text { dari gudang bahan baku AKA dan } \\
\text { menginput data bahan baku yang } \\
\text { telah terpenuhi. }\end{array}$ & $\begin{array}{l}\text { 1. Gudang bahan baku cabang dapat mendownload } \\
\text { data surat jalan untuk mengetahui jumlah bahan } \\
\text { baku yang dikirimkan. } \\
\text { 2. Menginput data bahan baku yang terpenuhi pada } \\
\text { sistem dengan memasukkan jumlah bahan baku } \\
\text { dengan jenis bahan baku yang sudah terdaftar } \\
\text { sesuai dengan pemesanan awal. } \\
\text { 3. Jika permintaan belum terpenuhi semua pada suatu } \\
\text { pengiriman bahan baku, Gudang bahan baku dapat } \\
\text { mengkonfirmasi kembali pesanan yang belum } \\
\text { datang atau belum dikirimkan. }\end{array}$ \\
\hline
\end{tabular}




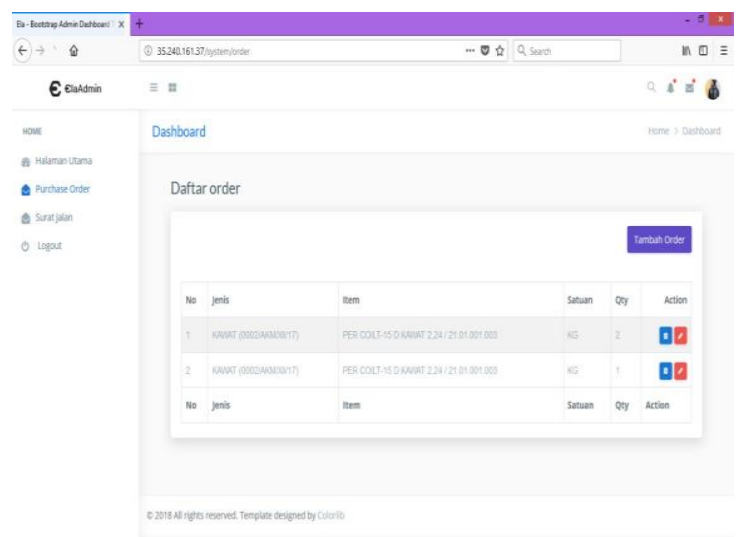

Gambar 8. Halaman Purchase Order role staf Admin Stok

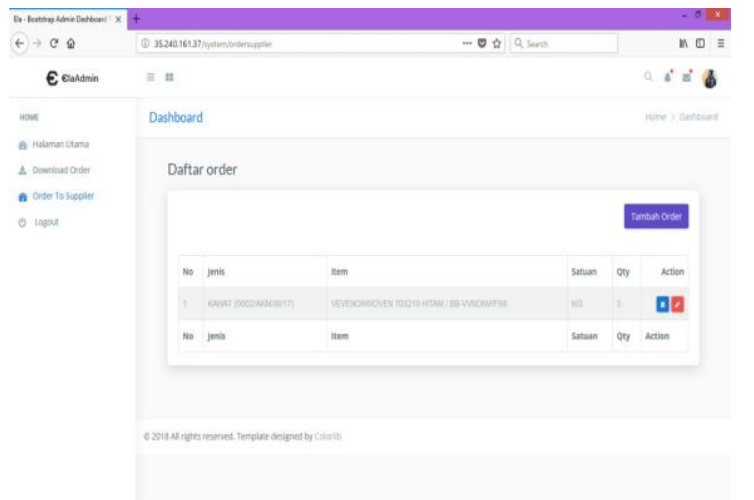

Gambar 10. Halaman Order to Supplier

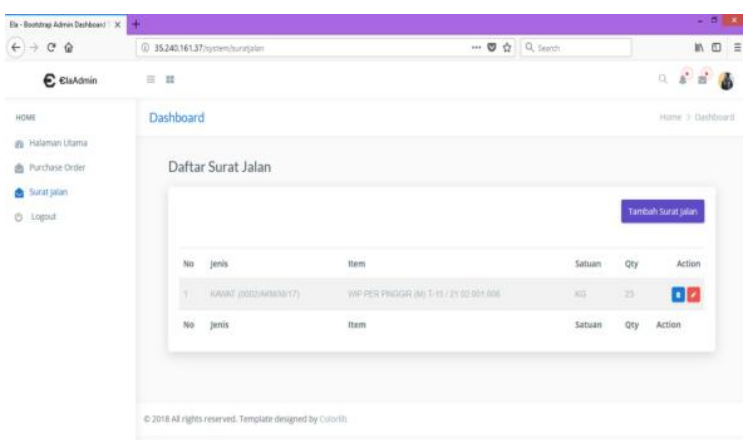

Gambar 12. Halaman Surat Jalan staf Admin Stok

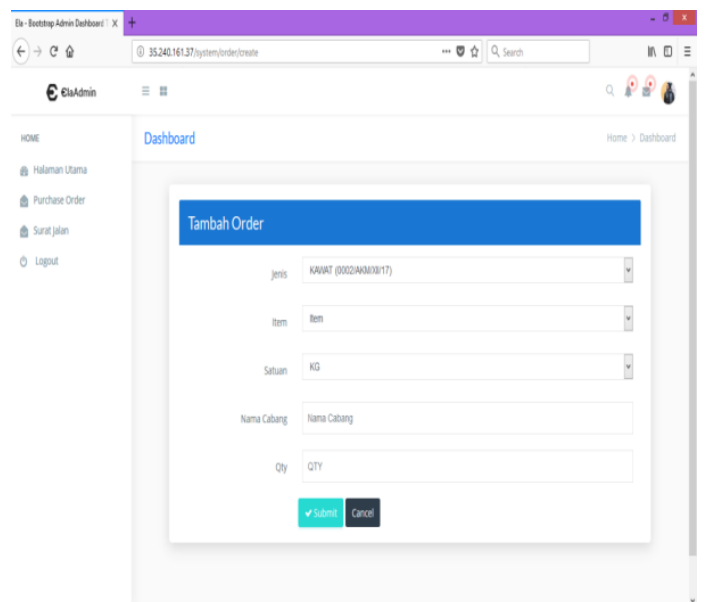

Gambar 9. Halaman Pemesanan Bahan

Baku

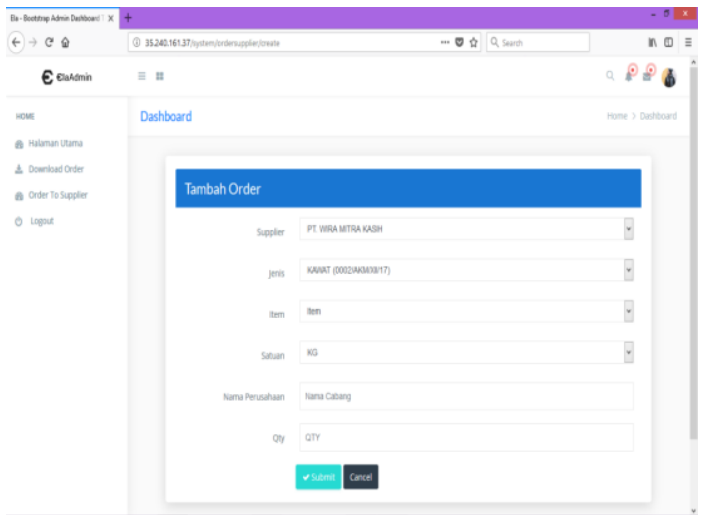

Gambar 11. Tampilan Halaman Order to Supplier lanjutan

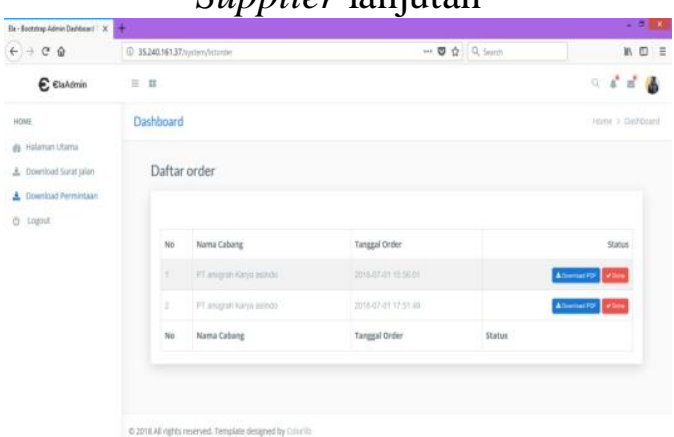

Gambar 13. Halaman Download Permintaan Cabang

Tampilan hasil rancangan sistem E-Supply Chain dengan pendekatan Value Matrix untuk proses pemesanan bahan baku diantaranya yaitu tampilan halaman Purchase Order role staf Admin Stok yang dapat dilihat pada Gambar 8, tampilan halaman pemesanan bahan baku pada Gambar 9, tampilan halaman Order to Supplier pada Gambar 10, Tampilan Halaman Order to Supplier lanjutan pada Gambar 11, tampilan halaman Surat Jalan staf Admin Stok pada Gambar 12 dan tampilan halaman Download permintaan dari cabang dapat dilihat pada Gambar 13. 
Perancangan Aplikasi Sistem E-Purchasing dengan Pendekatan Konsep Value Matrix pada Proses Pemesanan Bahan Baku

Carla Olyvia Doaly, Ahmad, Erwin Tanuwijaya

\section{KESIMPULAN}

Berdasarkan penelitian proses pemesanan bahan baku yang berlangsung selama ini di PT Anugrah Karya Aslindo, kesalahan pada pemesanan bahan baku dapat terjadi pada setiap departemen termasuk kesalahan yang dilakukan oleh Supplier dalam menerima request order maupun pengiriman bahan baku. Hasil Analisis yang dilakukan ditemukan bahwa kesalahan dalam pemesanan bahan baku disebabkan oleh sistem pemesanan bahan baku yang dilakukan secara manual sehingga menyulitkan setiap Departemen dalam proses pemesanan, ditunjukkan dengan sering terjadinya human error pada beberapa Departemen untuk proses input data, pencarian data supplier secara manual yang menyebabkan timbulnya kesalahan pada pemilihan supplier. Dengan dirancangnya sistem e-supply chain menggunakan pendekatan konsep Value Matrix pada proses pemesanan bahan baku maka dapat memperbaiki proses pemesanan bahan baku menjadi lebih efektif dan efesien karena adanya integrasi antara semua departemen yang terkait.

\section{DAFTAR PUSTAKA}

[1]. Maulina, Cahyantika, 2017, Pengaruh Dimensi Kualitas Produk Terhadap Keputusan Pembelian Konsumen Spring Bed Merk Ocean American (Studi di Jombang Jawa Timur.

[2]. Prakoso, Mikael Adisurya, 2015, E-Supply Chain Management dan Implementasinya (Studi Kasus PT Carrefour Indonesia). Program Studi Teknik Industri Institut Teknologi Bandung.

[3]. Ross, D.F., Introduction to e-Supply Chain Management, Enabling Technology to Build Market Winning Business Partnership, St. Lucie Press Florida, 2003.

[4]. Chopra, S., Meindl, P., 2001. Supply Chain Management, Prentice Hall, and New York.

[5]. Rayport,J.F., Sviokla, J.J.1995. Exploiting the virtual value chain. Harvard Business Review.

[6]. Indrajit, R. E. dan Richardus D., 2002, Konsep Manajemen Supply Chain. PT Gramedia Widiasarana Indonesia, Jakarta.

[7]. Shafiq,S.I, Sanin,C.,Szczerbicki,E.,Toro,C.,2015.Virtual Engineering Object / Virtual Engineering Process: A specialized form of Cyber Physical System for Industrie 4.0. Procedia Computer Science Volume 60, 2015, Pages 1146-1155. 